Journal of Contemporary Research in Business, Economics and Finance

ISSN: 2641-0265

Vol. 2, No. 4, pp. 71-82

2020

Publisher: Learning Gate

DOI: 10.33094/26410265.2020.24.71.82

(C) 2020 by the authors; licensee Learning Gate

\title{
Small Scale Enterprise Structure and Industrial Relations in Port Harcourt City
}

\author{
Biobele Richards Briggs \\ Department of Business Administration and Management Kenule Beeson Saro-Wiwa Polytechnic Bori, Rivers State, Nigeria. \\ Lenu Goodluck Wege \\ Department of Business Administration and Management Kenule Beeson Saro-Wiwa Polytechnic Bori, Rivers State, Nigeria. \\ Lebari Benson Nwiana \\ Department of General Studies Kenule Beeson Saro-Wiwa Polytechnic Bori, Rivers State, Nigeria. \\ Email: briggs.biobele@kenpoly.edu.ng
}

Received: 3 September 2020; Revised: 7 October 2020; Accepted: 19 October 2020; Published: 28 October 2020 Abstract: This study investigated the effect of small scale enterprise structure on industrial relations in Port Harcourt city, Nigeria. Descriptive survey design was employed and the study essentially utilized the questionnaire survey. In addition, field instrument from observation and personal interview were triangulated with review of relevant literature to cover different scope of the study. A total of 255 questionnaires were administered to the survey respondents from three small scale enterprises and 15 respondents each from five different sectors. Of the 225 questionnaires distributed, 199 usable questionnaires were returned yielding a response rate of $88.44 \%$. The data were analyzed using frequency percentage for descriptive analysis, Pearson's correlation coefficient $(r)$ to determine the strength of relationship between small scale enterprise structure and industrial relations and chi-square ( $\chi 2$ ) for testing the postulated hypothesis. The findings revealed that small scale enterprise structure negatively affects industrial relations because of rigid, one channel communication (downward) and generalized task structure employed by small business enterprises in Port Harcourt city. Based on the findings, it was recommended that small businesses in Port Harcourt city should design enterprise structure that will induce relative flexibility, union formation, specialized task and an ideal relationship of gains, trust and respect. This will invoke harmonious relations for the purposes of production, profitability and sustained benefits.

Keywords: Employee Performance, Industrial harmony, Industrial relations, Industrial relations Structure, Small business enterprises.

\section{Introduction}

An enterprise irrespective of its size and structure is a business organization comprising people or groups with predetermined goals, differentiated functions and a continuous life (Agbonifoh, Ehiametalor, Inegbenebor, \& Iyayi, 1999). Onuoha (1991) and Ile (2000) cited in Chikere (2010) affirm that a business enterprise is a legitimate human activity that produces and distributes goods and services for the satisfaction of needs and wants at a profit. The Organization for Economic Co-operation and Development (https://data.oecd.org/entrepreneur/enterprises-by-business-size.htm) categorized types of enterprises by size into small scale, medium-sized and large enterprises primarily based on number of employees. Furthermore, the Nigerian Bank of Industry (https://www.boi.ng/smedefinition/) identifies total assets and annual turnover as major determinants of the types of enterprises by size. Going by Njoku, Nwosu, and Callistus (2017) submission, an enterprise regardless of its size translates business idea into a planned and value added outcome. The 
structural requirement for a large scale enterprise demands onerous startups and a huge capital investment, making entry and management relatively more difficult and risky. Ugiagbe, Nwaogwugwu, and Obuseh (2008) assert that a large enterprise is characterized by impersonal relations formed structure. Agu (2001) posits that it is difficult to achieve a balanced and sustainable economic growth relying only on large enterprises. Thus, a small scale enterprise is an inexorable business organization that responds to time of economic change, stimulates indigenous entrepreneurship, and contributes to enhanced production and income (Ugiagbe et al., 2008) with a relatively low capital requirement (Njoku et al., 2017). There is no consensus on the definition of a small scale enterprise because of structural and economic differences in different locations. Oparaku (2013) describes a small scale enterprise as a business organization owned and controlled by one or few persons with direct owner's influences in decision making and having a relatively small share of the market and a relatively low capital requirement. Small Business Administration of USA cited in Ayozie, Jacob, Umukoro, and Ayozie (2013) identifies relatively low number of employees and low annual sales turnover, relatively minimal sales volume and minimal financial strength, local operations and independent management as key characteristics of a small scale enterprise. Njoku et al. (2017) advance that a small scale enterprise comprise low managerial skills and a low specialization structure.

In relation to enterprise structure, Njoku and Nwosu (2010) affirm that an enterprise divides, groups and coordinates activities into relationships with identification and differentiation of formal levels of authorities, responsibilities, channels of communication and power centres. Cole (2004) posits that the number of alternatives in designing an enterprise structure depends on the goals, tasks, features of enterprise members and other relevant environmental factors. Relatedly, Obijuru (2007) affirms that a small scale enterprise structure is designed compatible with environmental conditions to promote cordial relationship. Briggs (2002) posits that a small scale enterprise structure is not only mechanistic in nature but also takes the form of humanistic architecture to propel forces behind a good industrial relations practice which is critical to the overall enterprise (Casio, 1986). Regarding industrial relations, Ackers (2002) posits that industrial relations is a multidisciplinary field and the disciplinary areas that contribute to the field are organizational behaviour (Iwueke, 2016) labour economics, labour law, industrial psychology, industrial sociology (Bussing, 2002) and human resources management (Peretomode \& Peretomode, 2001). Kaufman (2008) submits that industrial relations has three facets namely science building, problem solving and ethical. In relation to science building, industrial relations seeks to identify employment problems through behavioural science research. The problem solving facet uses findings from behavioural research in solving labour relations problems through formulation of structural frameworks and policies. The ethical aspect views industrial relations as an ideal relationship of value, mutual trust and benefit (Iwuoha \& Chikwendu, 2014).

Industrial relations is a complex outcome of employer and employee living harmoniously in a work setting for the purposes of production, profitability and sustained benefits of the parties based on formal regulation of employment. Oriyomi, Yinusa, Abdullateef, Omede, and Abdulrasheed (2016) submit that good industrial relations is indispensible to the stability of a business enterprise because it stimulates an ideal relationship of mutual understanding, trust, team spirit and co-operation amongst the key actors. Iwuoha and Chikwendu (2014) contribute that industrial relations is the application of the principles of effective employer and employee relationship in a formally organized enterprise for mutual and sustained benefits based on the past and present environmental realities. There is a challenge because of the common notion that maintenance of a good industrial relations practice has little or no relevance in a small scale enterprise. Similarly, despite the significant contributions of small scale enterprises in economic development especially in developing countries like Nigeria, small businesses still strive for success because of financial problems, competition, technological problems, managerial inefficiency and enterprise structural defects. A defective enterprise structure negatively affects organizational members because it induces task ambiguity, task overload, stress, low employee morale, low productivity, high employee turnover and conflict. The outcome of a defective structure invokes organic problems in the 
enterprise which this study attempts to solve. Consequently, this study aims to investigate the effect of small scale enterprise structure on industrial relations in Port Harcourt city.

The dimensions of small scale enterprise structure in this study are essential ingredients of organizational structure namely span of control, hierarchy of command, authority, division of labour, channel of communication and task (Njoku \& Nwosu, 2010). Likewise, the measures of industrial relations are significant elements of a good industrial relations practice namely ideal relationship, collectivism, industrial harmony and employee performance (Iwuoha \& Chikwendu, 2014). The study is therefore compelling because of undesirable consequences of industrial relations such as grievances, conflicts, strikes inefficiency and ineffectiveness caused by enterprise structural failure.

The following research objectives are stated to summarize what is to be achieved in the study:

I. To identify the prevalent types of small scale enterprise structure by sectors in Port Harcourt city.

II. To determine the effect of small scale enterprise span of control on ideal relationship in Port Harcourt city.

III. To ascertain the effect of centralization in small scale enterprise on collectivism in Port Harcourt city.

IV. To ascertain the effect of communication in small scale enterprise on industrial harmony in Port Harcourt city.

V. To determine the effect of task in small business enterprise on employee performance in Port Harcourt city.

The following research questions serve as a guide to the study in the quest to provide answers in line with the study's objectives:

I. What are the prevalent types of small scale enterprise structure by sectors in Port Harcourt city?

II. To what extent does small scale enterprise span of control affect ideal relationship in Port Harcourt city?

III. To what extent does centralization in small scale enterprise affect collectivism in Port Harcourt city?

IV. To what extent does communication in small scale enterprise affect industrial harmony in Port Harcourt city?

V. To what extent does task in small business enterprise affect employee performance in Port Harcourt city?

The following null hypothesis is formulated to guide the study:

Ho: There is no significant difference between small scale enterprise structure and industrial relations in Port Harcourt city.

The rationale behind this study is to promote mutual understanding amongst enterprise members, reduce industrial disputes and ensure production continuity in small scale enterprises in Port Harcourt city and Nigeria at large. The findings and recommendations of this study will be of benefit to small scale enterprise employees and employers in stimulating harmonious relationship that will enhance productivity and economic growth. Third parties and trade unions will likewise benefit from the findings and recommendations of the study in the areas of negotiations and agreement strategies. Finally, researchers and students of business administration, management studies and allied courses will benefit from the findings and recommendations of the study because it will serve as an additional source of knowledge for problem recognition and analysis. This study is delimited to Port Harcourt city because it is an oil rich State capital that hosts several commercial enterprises of different sizes and in different sectors of the economy.

\subsection{Concept of Enterprise Structure}

An enterprise structure is a system of task and reporting relationships that coordinates and motivates enterprise members to work together and achieve predetermined goals. An Enterprise 
structure comprises line, line and staff, functional, project and matrix (Briggs, 2002) and it is designed from both mechanistic and humanistic spheres. Njoku and Nwosu (2010) stress that the mechanistic system is characterized by reliance on formal rules and regulations, centralization of decision making, narrowly defined job responsibilities and a rigid hierarchy of authority while Briggs (2002) views the humanistic system as a web of human interactions within social groups with different attitudes and aspirations. Jones, George, and Hill (2000) opine that an enterprise strategy, technology and human resources are the fundamental factors that affect enterprise structure. Robbins (1988) cited in Njoku and Nwosu (2010) explains an enterprise structure based on degrees namely complexity, formalization and authority. A suitable enterprise structure clearly shows chain of command and span of control, identifies weaknesses resulting from channel of communication and improves the relationships and areas of responsibilities in the enterprise. A poor enterprise structure causes communication problems, low employee morale, lack of motivation, low employee productivity and conflict. Iwueke (2016) identifies specialization, interdependence, common resources, goal difference and authority relationships as predominant structural factors that cause conflict in an enterprise.

\subsection{Concept of Small Scale Enterprise in Nigeria}

There is no universally acceptable concept of a small scale enterprise in Nigeria since it is explained from different contexts by many institutions and scholars based on environmental circumstances (Agu, 2001). For instance, The Federal Government small scale development plan (1980) describes a small scale enterprise in Nigeria as a business outfit with a capital not exceeding N150, 000 in manufacturing and equipment alone. The Centre for Management Development (CMD) defines a small scale enterprise as a business outfit that employs not more than 50 full-time employees as at 1982 (Ayozie et al., 2013). These two elucidations are limited to two principal criteria namely capital employed and number of employees. Recently, the Bank of Industry (BOI) uses number of employees, total assets and annual turnover to describe a small scale enterprise in relation to loan amounts qualification. Accordingly, a small scale enterprise is a business organization that engages not less than 11 and not more than 50 employees with total assets of not less than N5 million and not more than N100 million and an annual turnover not exceeding N100 million. A business enterprise with activities less than the criteria of a small scale enterprise set by the BOI is categorized as a micro-enterprise. Consequent upon environmental complexities and realities in Nigeria, a small scale enterprise is a legitimate business outfit that is independently managed with not more 50 employees and having a relatively small share of the market and a relatively small financial requirement.

Small scale enterprises constitute a significant proportion of businesses in Port Harcourt city and Nigeria in general. The Federal Office of Statistics cited in Obi (2015) indicates that about $97 \%$ of all Nigerian enterprises are small scale businesses and they engage approximately $50 \%$ of the working population and equally contribute approximately 50\% of the country's output. Agu (2001) identifies small businesses roles to national economy as employment generation, indigenous entrepreneurship development, spring board for large scale enterprises and industrialization of rural areas. A significant number of small scale enterprises in Nigeria operate in the informal sector. Njoku et al. (2017) identify insufficient capital, poor managerial skill, poor motivation and personalized management as major causes of small businesses failure in Nigeria. Briggs (2009) acknowledges adverse government policies, lack of dependable business relationship, low market patronage, undue competition from large enterprises and lack of requisite entrepreneurial traits like sincerity, innovation, business skills and risk taking propensity as key factors affecting small scale enterprises.

\subsection{Approaches to Industrial Relations}

Zeb-Obipi (2007) posits that the approach to industrial relations depends on three factors namely analytical convenience, parsimony and contingency of thought. Iwuoha and Chikwendu (2014) describe industrial relations as an activity that promotes ideal relationship encompassing effective communication, honest dealing with one another and mutual gains, trust and respect. The approaches to 
industrial relations are derived from different perspectives based on institutions, processes, principles, activities, organizational productivity and profitability. From the institutional perspective, industrial relations involves bargaining between respective institutions representing the primary actors of an enterprise comprising labour unions, employers association and a third party (Panigrahi, 2006). The process perspective views industrial relations as a process of promoting and sustaining an ideal relationship of peace and harmony (Briggs, 2014). Poole (1986) posits that the principles and activities of industrial relations focus on conflict, accommodation and reconciliation of the principal actors caused by conflicting interests. An industrial relations theory examines the different approaches and postulates propositions to present and specify the relationship between employee and employer and other related parties in an enterprise. Panigrahi (2006) recognizes dealing with variables to determine input and output relationship, establishing interrelationship between individualism and collectivism, testing hypothesis and predicting quality as good qualities of an industrial relations theory.

Briggs (2014) identifies unitary, conflict, marxist and system theories as fundamental theories of industrial relations. The unitary theory emphasizes on oneness, mutual co-existence and group pursuits of common purpose. Consequently, unions are considered unnecessary because the theory does not recognize conflict, divisive tendencies and tension (Iwuoha \& Chikwendu, 2014). The conflict (pluralism) theory stresses on having different groups of people with divergent interests, loyalties, set of objectives and leaders. As a result, conflict is rational and inevitable in organizations and trade union is a legitimate representative of employees. The marxist theory sees industrial relations as a nature of capitalist society in the workplace where there is division between capital and labour because of inequality in social and economic arrangements. Consequently, conflict is unavoidable and trade unions are expected outcome from exploitation (Panigrahi, 2006). Finally, the system theory views industrial relations as an interaction of interrelated parts having inputs (the primary actors), processes (collective bargaining, joint participation, industrial actions and conflict resolution) and outputs/outcomes (collective agreement, labour legislation, enterprise commitment) (Iwuoha \& Chikwendu, 2014). The system theory emphasizes on the significance of the environmental influence such as technological characteristics, market or budgetary constraints and the locus and distribution of power in the larger society.

\section{Methodology}

This study employed the descriptive survey design to enable the researcher collect objective data and describe the problem being investigated (Ezirim, Briggs, Ebiringa, Akpobolokemi, \& Maclayton, 2004) without manipulations and controls (Igbara, 2012). The questionnaire survey was the major instrument employed in this study and instrument was carefully constructed in consideration to adequacy, questions sequence and wording in order to elicit correct responses from the respondents. In relation to validity of the instrument, the instrument guides were given to professional colleagues to assess the appropriateness of the content and make necessary corrections. Regarding reliability of the instrument, the test-retest method (Kothari, 2004) was employed to ascertain the correlation coefficient between the two sets of test administered, using Spearman's rank correlation coefficient. The correlation coefficient was 0.99 signifying that the measuring instrument was reliable. Apart from the questionnaire method, field instruments from observations and personal interviews were triangulated with the review of relevant literature to cover requisite elements of the study.

Purposive sampling method (Igbara, 2012) was employed to select three small scale enterprises and 15 respondents each from five different sectors namely automobile workshop, fashion and tailoring, fish farming, general trade (buying and selling) and water factory. The reason for using purposive sampling was to identify and deliberately draw samples from typical cases related to the subject under investigation. Unavailable data in respect of the number of small scale enterprises in Port Harcourt city and the multidimensional characteristics of small scale enterprises also influenced the use of purposive sampling technique. The selected enterprises were deliberately drawn to meet the BOI minimum 
criterion on number of employees, that is, not less than 11 and not more than 50. Furthermore, the reason for using five different sectors was to get broad and diverse data for the study.

In processing the data for analysis, the data was edited, coded, classified ant tabulated according to the sectors and enterprises. Descriptive survey analysis (percentage frequency distribution) was employed. A percentage frequency distribution displays data that specifies the proportion (by 100\%) of observations that exist for each data point or grouping of data points. It is a useful method of expressing the relative frequency of survey responses and other data (Igbara, 2012). Furthermore, the Pearson's correlation coefficient ( $r$ ) was used to determine the strength of relationship between small scale enterprise structure and industrial relations and, finally, Chi-square $\left(\chi^{2}\right)$ at $5 \%$ level of significance was used to test the stated null (Ho) hypothesis. A total of 225 questionnaires were administered to the survey respondents from the three small scale enterprises and 15 respondents each from five different sectors as earlier explained. Of the total questionnaires distributed, 199 usable questionnaires were returned yielding a response rate of $88.44 \%$. The sub-total response rates by sectors are automobile workshop 35 (15.55\%), fashion and tailoring 41 (18.22\%), fish farming 43 (19.11\%), general trade (buying and selling) $37(16.44 \%)$ and water factory $43(19.11 \%)$. The sub-total response rates by enterprises are enterprise [1] 66 (29.33), enterprise [2] 66 (29.33\%) and enterprise [3] 67 (29.77\%). A breakdown of the sample subjects by the respective sectors and enterprises is shown in Table 1.

Table-1.

Sample by Sectors and Enterprises.

\begin{tabular}{c|c|c|c|c}
\hline Sectors & Enterprise 1 & Enterprise 2 & Enterprise 3 & Total \\
\hline Automobile Workshop & $11(4.89 \%)$ & $12(5.33 \%)$ & $12(5.33 \%)$ & $35(15.55 \%)$ \\
\hline Fashion \& Tailoring & $14(6.22 \%)$ & $13(5.78 \%)$ & $14(6.22 \%)$ & $41(18.22 \%)$ \\
\hline Fish Farming & $14(6.22 \%)$ & $15(6.67 \%)$ & $14(6.22 \%)$ & $43(19.11 \%)$ \\
\hline Trade (Buying \& Selling) & $12(5.33 \%)$ & $12(5.33 \%)$ & $13(5.78 \%)$ & $37(16.44 \%)$ \\
\hline Water Factory & $15(6.67 \%)$ & $14(6.22 \%)$ & $14(6.22 \%)$ & $43(19.11 \%)$ \\
\hline Total & $66(29.33)$ & $66(29.33 \%)$ & $67(29.77 \%)$ & $199(88.44 \%)$ \\
\hline
\end{tabular}

Source: Field survey (2020).

\section{Data Analysis and Findings}

Small Scale Enterprise Structure by Sectors: To identify the prevalent types of small scale enterprise structure by sectors in Port Harcourt city, respondents were requested to indicate their respective enterprise structures based on the dimensions of the independent variable. Two options were given to each of the dimensions and the percentage responses Table 2 are span of control (narrow 22 signifying $11.06 \%$ and wide 177 signifying 88.94\%), hierarchy of command (strict adherence 189 signifying $94.97 \%$ and moderate adherence 10 signifying 5.03\%), authority (centralized 182 signifying $91.46 \%$ and decentralized 17 signifying 8.54\%), division of labour (intense 81 signifying $40.70 \%$ and mild 118 signifying $59.30 \%$ ), communication channel (one channel 149 signifying $74.87 \%$ and more than a channel 50 signifying $25.13 \%$ ) and task (specialized 75 signifying $37.69 \%$ and general 124 signifying $62.31 \%$ ). The findings revealed that small scale enterprise structure in Port Harcourt city predominantly employs wide span of control, adheres strictly to hierarchy of command, utilizes centralized structure and uses mild division of labour. Also, it was established that small scale enterprise structure in Port Harcourt city predominantly employs one channel of communication (downward) and performs more of generalized tasks than specialized tasks. 
Table-2.

Small scale enterprises structure by sectors.

\begin{tabular}{|c|c|c|c|c|c|c|c|}
\hline $\mathbf{S} / \mathbf{N}$ & $\begin{array}{c}\text { Measures of } \\
\text { Enterprise } \\
\text { Structure }\end{array}$ & $\begin{array}{l}\text { Automobile } \\
\text { Workshop }\end{array}$ & $\begin{array}{c}\text { Fashion } \\
\& \\
\text { Tailoring }\end{array}$ & $\begin{array}{c}\text { Fish } \\
\text { Farming }\end{array}$ & $\begin{array}{c}\text { Trade } \\
\text { (Buying \& } \\
\text { Selling) }\end{array}$ & $\begin{array}{l}\text { Water } \\
\text { Factory }\end{array}$ & Total \\
\hline \multirow[t]{3}{*}{1.} & \multicolumn{7}{|c|}{ Span of Control } \\
\hline & Narrow & $\begin{array}{c}2 \\
(5.71 \%) \\
\end{array}$ & $\begin{array}{c}3 \\
(7.32 \%) \\
\end{array}$ & $\begin{array}{c}5 \\
(11.63 \%) \\
\end{array}$ & $2(5.41 \%)$ & $10(23.26 \%)$ & $\begin{array}{c}22 \\
(11.06 \%) \\
\end{array}$ \\
\hline & Wide & $\begin{array}{c}33 \\
(94.29 \%) \\
\end{array}$ & $\begin{array}{c}38 \\
(92.68 \%) \\
\end{array}$ & $\begin{array}{c}38 \\
(88.37 \%) \\
\end{array}$ & $\begin{array}{c}35 \\
(94.59 \%) \\
\end{array}$ & $33(76.74 \%)$ & $\begin{array}{c}177 \\
(88.94 \%) \\
\end{array}$ \\
\hline \multirow[t]{3}{*}{2.} & \multicolumn{7}{|c|}{ Hierarchy of Command } \\
\hline & $\begin{array}{c}\text { Strict } \\
\text { adherence }\end{array}$ & $\begin{array}{c}34 \\
(97.14 \%) \\
\end{array}$ & $\begin{array}{c}39 \\
(95.12 \%) \\
\end{array}$ & $\begin{array}{c}42 \\
(97.67 \%) \\
\end{array}$ & $\begin{array}{c}36 \\
(97.30 \%) \\
\end{array}$ & $\begin{array}{c}38 \\
(88.37 \%) \\
\end{array}$ & $\begin{array}{c}189 \\
(94.97 \%) \\
\end{array}$ \\
\hline & $\begin{array}{l}\text { Moderate } \\
\text { adherence }\end{array}$ & $\begin{array}{c}1 \\
(2.86 \%) \\
\end{array}$ & $\begin{array}{c}2 \\
(4.88 \%) \\
\end{array}$ & $\begin{array}{c}1 \\
(2.33 \%) \\
\end{array}$ & $\begin{array}{c}1 \\
(2.70 \%) \\
\end{array}$ & $\begin{array}{c}5 \\
(11.63 \%) \\
\end{array}$ & $\begin{array}{c}10 \\
(5.03 \%) \\
\end{array}$ \\
\hline \multirow[t]{3}{*}{3.} & \multicolumn{7}{|c|}{ Authority } \\
\hline & Centralized & $\begin{array}{c}34 \\
(97.14 \%) \\
\end{array}$ & $\begin{array}{c}30 \\
(73.17 \%) \\
\end{array}$ & $\begin{array}{c}42 \\
(97.67 \%) \\
\end{array}$ & $\begin{array}{c}35 \\
(94.59 \%) \\
\end{array}$ & $\begin{array}{c}41 \\
(95.35 \%)\end{array}$ & $\begin{array}{c}182 \\
(91.46 \%) \\
\end{array}$ \\
\hline & Decentralized & $\begin{array}{c}1 \\
(2.86 \%)\end{array}$ & $\begin{array}{c}11 \\
(26.83 \%)\end{array}$ & $\begin{array}{c}1 \\
(2.33)\end{array}$ & $\begin{array}{c}2 \\
(5.41 \%)\end{array}$ & $\begin{array}{c}2 \\
(4.65 \%)\end{array}$ & $\begin{array}{c}17 \\
(8.54 \%)\end{array}$ \\
\hline \multirow[t]{3}{*}{4.} & \multicolumn{7}{|c|}{ Division of labour } \\
\hline & Intense & $\begin{array}{c}2 \\
(5.71 \%)\end{array}$ & $\begin{array}{c}29 \\
(70.73 \%)\end{array}$ & $\begin{array}{c}10 \\
(23.26 \%) \\
\end{array}$ & $\begin{array}{c}14 \\
(37.88 \%)\end{array}$ & $\begin{array}{c}26 \\
(60.47 \%) \\
\end{array}$ & $\begin{array}{c}81 \\
(40.70 \%) \\
\end{array}$ \\
\hline & Mild & $\begin{array}{c}33 \\
(94.29 \%) \\
\end{array}$ & $\begin{array}{c}12 \\
(29.27 \%)\end{array}$ & $\begin{array}{c}33 \\
(76.74 \%) \\
\end{array}$ & $\begin{array}{c}23 \\
(62.16 \%) \\
\end{array}$ & $\begin{array}{c}17 \\
(39.53 \%)\end{array}$ & $\begin{array}{c}118 \\
(59.30 \%) \\
\end{array}$ \\
\hline \multirow[t]{3}{*}{5.} & \multicolumn{7}{|c|}{ Communication flow } \\
\hline & One channel & $\begin{array}{c}31 \\
(88.57 \%)\end{array}$ & $\begin{array}{c}19 \\
(46.34 \%)\end{array}$ & $\begin{array}{c}29 \\
(67.44 \%)\end{array}$ & $\begin{array}{c}31 \\
(83.78 \%)\end{array}$ & $\begin{array}{c}39 \\
(90.70 \%)\end{array}$ & $\begin{array}{c}149 \\
(74.87 \%)\end{array}$ \\
\hline & $\begin{array}{l}\text { More than } \\
\text { one channel }\end{array}$ & $\begin{array}{c}4 \\
(11.43 \%)\end{array}$ & $\begin{array}{c}22 \\
(53.66 \%)\end{array}$ & $\begin{array}{c}14 \\
(32.56 \%)\end{array}$ & $6(16.22 \%)$ & $\begin{array}{c}4 \\
(9.30 \%)\end{array}$ & $\begin{array}{c}50 \\
(25.13 \%)\end{array}$ \\
\hline \multirow[t]{3}{*}{6.} & \multicolumn{7}{|c|}{ Task } \\
\hline & Specialized & $9(25.71 \%)$ & $\begin{array}{c}38 \\
(92.68 \%)\end{array}$ & $\begin{array}{c}8 \\
(18.60 \%)\end{array}$ & $\begin{array}{c}1 \\
(2.70 \%)\end{array}$ & $\begin{array}{c}19 \\
(44.19 \%)\end{array}$ & $\begin{array}{c}75 \\
(37.69 \%)\end{array}$ \\
\hline & Generalized & $\begin{array}{c}26 \\
(74.29 \%)\end{array}$ & $3(7.32 \%)$ & $\begin{array}{c}35 \\
(81.40 \%)\end{array}$ & $\begin{array}{c}36 \\
(97.30 \%)\end{array}$ & $\begin{array}{c}24 \\
(55.81 \%)\end{array}$ & $\begin{array}{c}124 \\
(62.31 \%)\end{array}$ \\
\hline
\end{tabular}

Source: Field survey (2020).

Small Scale Enterprise Structure and Industrial Relations: To analyze the effect of small scale enterprise structure on industrial relations in Port Harcourt city, the study employed the rating multiple choice questions. Though, the rating multiple choice structure does not define the level of scale, it is however useful in survey research because it allows respondents to provide comprehensive information since they answer the entire question options. The structure also gives room for different responses towards the same phenomenon.

A 5-point Likert rating scale (Kothari, 2004) multiple choice questions was used and the scale ranged from $1-5$ signifying 1 - 'very low extent', 2 - 'low extent', 3 - 'uncertain', 4 - 'high extent' and 5 - 'very high extent'. The essence of using this rating scale was to encourage respondents to use full width of opinion and avoid errors of central tendency (Igbara, 2012). To avoid vagueness in the analysis, the 2 extreme categories of 1 - 'very low extent' and 5 - 'very high extent' were merged into 2 and 4 . respectively. Consequently, the new rating structure is 2 - 'low extent', 3 - 'uncertain' and 4 - 'high extent'. 
The percentage responses with a mean of 2.77 Table 3 regarding the extent to which small scale enterprise structure dimensions influences industrial relations measures in Port Harcourt city are: span of control and ideal relationship - low extent 9 (1.63\%), uncertain $28(5.08 \%)$, high extent $106(19.24 \%)$; centralization and collectivism - low extent 13 (2.36\%), uncertain $23(4.17 \%)$, high extent $109(19.78 \%)$; communication and industrial harmony - low extent 2 (0.36\%), uncertain 13 (2.36\%), high extent 117 (21.23\%); and task and employee performance - low extent 1 (0.18\%), uncertain $14(2.54 \%)$, high extent $116(21.05 \%)$. The findings revealed that all the dimensions of small scale enterprise structure to a high extent influence industrial relations measures.

Table-3.

Small scale enterprise structure and industrial relations practice

\begin{tabular}{|c|c|c|c|c|}
\hline Measures/Dimensions & 2- Low Extent & 3 - Uncertain & 4-High Extent & Total \\
\hline $\begin{array}{l}\text { Span of Control and } \\
\text { Ideal Relationship }\end{array}$ & $\begin{array}{c}9 \\
(1.63 \%) \\
\end{array}$ & $\begin{array}{c}28 \\
(5.08 \%)\end{array}$ & $\begin{array}{c}106 \\
(19.24 \%)\end{array}$ & $\begin{array}{c}143 \\
(25.95 \%)\end{array}$ \\
\hline $\begin{array}{ll}\text { Centralization } & \text { and } \\
\text { Collectivism } & \end{array}$ & $\begin{array}{c}13 \\
(2.36 \%)\end{array}$ & $\begin{array}{c}23 \\
(4.17 \%)\end{array}$ & $\begin{array}{c}109 \\
(19.78 \%)\end{array}$ & $\begin{array}{c}145 \\
(26.31 \%)\end{array}$ \\
\hline $\begin{array}{l}\text { Communication and } \\
\text { Industrial Harmony }\end{array}$ & $\begin{array}{c}2 \\
(0.36 \%)\end{array}$ & $\begin{array}{c}13 \\
(2.36 \%) \\
\end{array}$ & $\begin{array}{c}117 \\
(21.23 \%)\end{array}$ & $\begin{array}{c}132 \\
(23.95 \%) \\
\end{array}$ \\
\hline $\begin{array}{l}\text { Task and Employee } \\
\text { Performance }\end{array}$ & $\begin{array}{c}1 \\
(0.18 \%)\end{array}$ & $\begin{array}{c}14 \\
(2.54 \%)\end{array}$ & $\begin{array}{c}116 \\
(21.05 \%)\end{array}$ & $\begin{array}{c}131 \\
(23.77 \%)\end{array}$ \\
\hline Total & $\begin{array}{c}25 \\
(4.54 \%) \\
\end{array}$ & $\begin{array}{c}78 \\
(14.16 \%)\end{array}$ & $\begin{array}{c}448 \\
(81.31 \%)\end{array}$ & $\begin{array}{c}551 \\
(100 \%) \\
\end{array}$ \\
\hline
\end{tabular}

Table-4.

Relationship between small scale enterprise structure and industrial relations practice.

\begin{tabular}{l|c|c|c}
\hline Sector & Yes & No & Total \\
\hline Automobile Workshop & $8(4.02 \%)$ & $27(13.57 \%)$ & $35(17.59 \%)$ \\
\hline Fashion \& Tailoring & $11(5.53 \%)$ & $30(15.07 \%)$ & $41(20.60 \%)$ \\
\hline Fish Farming & $12(6.03 \%)$ & $31(15.58 \%)$ & $43(21.61 \%)$ \\
\hline Trade (Buying \& Selling) & $18(9.04 \%)$ & $19(9.55 \%)$ & $37(18.59 \%)$ \\
\hline Water Factory & $9(4.52 \%)$ & $34(17.08 \%)$ & $43(21.60 \%)$ \\
\hline Total & $58(29.15 \%)$ & $141(70.85)$ & $199(100 \%)$ \\
\hline
\end{tabular}

Source: Field survey (2020).

Correlation coefficient: To ascertain if there is a positive or negative correlation coefficient between small scale enterprise structure and industrial relations in Port Harcourt city, the Pearson's correlation coefficient $(r)$ was employed and the formula is:

$$
r=\frac{n\left(\sum x y\right)-\left(\sum x\right)\left(\sum y\right)}{\sqrt{\left[n\left(\sum x^{2}\right)-\left(\sum x\right)^{2}\right]\left[n\left(\sum y^{2}\right)-\left(\sum y\right)^{2}\right]}}
$$

Where:

$\mathrm{n}=$ number of pairs of responses.

$\Sigma \mathrm{xy}=$ sum of the products of paired responses.

$\Sigma \mathrm{x}=$ sum of $\mathrm{x}$ responses.

$\Sigma \mathrm{y}=$ sum of y responses.

$\Sigma \mathrm{x}^{2}=$ sum of squared of $\mathrm{x}$ responses.

$\Sigma \mathrm{y}^{2}=$ sum of squared of $\mathrm{y}$ responses. 
Data for the computation of Pearson's correlation coefficient $(r)$ is derived from survey responses Table 4.

Table-5.

Calculated value of Pearson's correlation coefficient ( $\mathrm{r}$ ).

\begin{tabular}{c|c|c|c|c|c}
\hline $\mathbf{n}$ (Sectors) & $\mathbf{x}$ (Yes responses) & $\mathbf{y}$ (No responses) & $\mathbf{x}^{\mathbf{2}}$ & $\mathbf{y}^{\mathbf{2}}$ & $\mathbf{x y}$ \\
\hline 1 & 8 & 27 & 64 & 729 & 216 \\
\hline 2 & 11 & 30 & 121 & 900 & 330 \\
\hline 3 & 12 & 31 & 144 & 961 & 372 \\
\hline 4 & 18 & 19 & 324 & 361 & 342 \\
\hline 5 & 9 & 34 & 81 & 1156 & 306 \\
\hline $\mathrm{N}=5$ & $\Sigma \mathrm{x}=58$ & $\Sigma \mathrm{y}=141$ & $\Sigma_{\mathrm{x}}^{2}=734$ & $\sum_{\mathrm{y}^{2}}=4107$ & $\Sigma \mathrm{xy}=1566$ \\
\hline
\end{tabular}

Source: Field survey (2020).

$$
r=\sqrt{\frac{5 \times 1566-58 \times 141}{\left[5 \times 734-(58)^{2}\right] \times\left[5 \times 4107-(141)^{2}\right]}}
$$

$r=-0.858$

The result $(\mathrm{r}=-0.858)$ showed that there is a high negative correlation coefficient between small scale enterprise structure and industrial relations in Port Harcourt city.

Hypothesis Testing: To determine if there is a significant difference between small scale enterprise structure and industrial relations in Port Harcourt city, the null hypothesis (Ho) was stated to guide the study as:

Ho: There is no significant difference between small scale enterprise structure and industrial relations practice in Port Harcourt city.

Chi-Square $\left(\chi^{2}\right)$ was used to test the stated hypothesis at $5 \%$ level of significance. The formula for Chi- Square $\left(\chi^{2}\right)$ is:

$\chi^{2}=\Sigma \frac{(O-E)^{2}}{E}$

Where:

$\mathrm{O}=$ Observed frequencies.

$\mathrm{E}=$ Expected frequencies.

$\Sigma=$ Summation.

The observed values are derived from survey responses Table 5. The calculated values are shown in Table 6.

The table value of $\chi^{2}$ for 4 degrees of freedom at $5 \%$ level of significance is 9.488. Comparing the calculated value (9.030) and table value (9.488), the calculated value is less than table value. Therefore, null hypothesis (Ho) is accepted. Thus, there is no significant difference between small scale enterprise structure and industrial relations in Port Harcourt city. The test result showed that small scale enterprise structure significantly influences industrial relations in Port Harcourt city. From the forgoing, it is deducible that small scale enterprise structure significantly and undesirably affects industrial relations in Port Harcourt city. 
Table-6.

Calculated Values of $\chi^{2}$.

\begin{tabular}{c|c|c|c|c}
\hline $\mathbf{O}$ & $\mathbf{E}$ & $\mathbf{O}-\mathbf{E}$ & $(\mathbf{O}-\mathbf{E})^{\mathbf{2}}$ & $(\mathbf{O}-\mathbf{E})^{\mathbf{2}} / \mathbf{E}$ \\
\hline 8 & 10.201 & -2.201 & 4.844 & 0.475 \\
\hline 27 & 24.799 & 2.201 & 4.844 & 0.195 \\
\hline 11 & 11.950 & -0.950 & 0.903 & 0.076 \\
\hline 30 & 29.050 & 0.950 & 0.903 & 0.031 \\
\hline 12 & 12.533 & -0.533 & 0.284 & 0.023 \\
\hline 31 & 30.467 & 0.533 & 0.284 & 0.009 \\
\hline 18 & 10.784 & 7.261 & 52.071 & 4.829 \\
\hline 19 & 26.216 & -7.216 & 52.071 & 1.986 \\
\hline 9 & 12.533 & -3.533 & 12.482 & 0.996 \\
\hline 34 & 30.467 & 3.533 & 12.482 & 0.410 \\
\hline$\Sigma(\mathrm{O}-\mathrm{E})^{2} / \mathrm{E}=9.030$ & & &
\end{tabular}

\section{Discussion}

An enterprise structure is a configuration of tasks and reporting relationships that coordinates and motivates enterprise members to work together and achieve predetermined goals. The purpose of an enterprise structure is to make human cooperation effective through span of control (also referred to as span of management). Span of control is the number of subordinates that can be managed effectively by a superior (Briggs, 2002). A span is either narrow with a relatively large number of hierarchical levels or wide with relatively low hierarchical levels (Njoku \& Nwosu, 2010).

In relation to span of control and ideal relationship, the survey established a significant but negative relationship. It was revealed that small scale enterprises in Port Harcourt city principally utilize a wide span of control which is consistent with Jones et al. (2000) assertion that a small scale enterprise naturally adopts a wide span of control. Weihrich, Cannice, and Koontz (2010) affirm that a wide span is a function of clear delegation, a well-defined task, an effective meeting and social relations amongst enterprise members. In contrast, the study established that tasks are not well defined because of mild division of labour and generalized task structure. Also, meetings and social relations are ineffective or lacking in most cases because of personalized and non-institutionalized structure of small enterprises in Port Harcourt. Consequently, the situation adversely affects delineation of authority, responsibility and accountability (Njoku \& Nwosu, 2010) and an ideal relationship of partnership, participation, team spirit and cooperation (Iwuoha \& Chikwendu, 2014). Regarding undefined tasks, it was established that reporting authority in small businesses in Port Harcourt is based on nonhierarchical structure which inhibits unity of command that fosters ideal relationship between superior and subordinates and invokes low employee morale that adversely affects harmonious relations for the purpose of mutual benefits.

Centralization is the concentration of authority at the top of management hierarchy (Jones et al., 2000). Briggs (2002) and Akanwa (2003) posit that centralized structure is only possible in a small scale enterprise that lacks flexibility and formal arrangement. Conversely, Rainnie (1985) asserts that small scale enterprises have higher flexible structure occurrence because they are not obstructed by institutional arrangements. However, the findings in this regard revealed that small enterprise structure in Port Harcourt use rigid and centralized structure that discourages initiative and creativity, social relations and machinery for cooperation. The finding is in line with Briggs and Akanwu affirmations.

Regarding centralization and collectivism, the response structure indicated a negative relationship. The study affirmed that the relationship is converse in nature due to the centralized and rigid structure of small scale enterprises in Port Harcourt. Collectivism recognizes group over individual in respect to achievements, benefits and performance and further sees performance as an aggregate ability and effort (Gelfand, Bhawuk, Nishii, \& Bechtold, 2004). Whereas a centralized and rigid structure undermines an 
enterprise of collective labour relations and promotes individualism that affects collective approach to negotiating workplace rules and policies (Casio, 1986).

Collectivism is associated with pluralism theory that recognizes union because of the divergent interests of labour and management. A significant number of respondents indicated non-existence of union in their respective enterprises and further stated that management does not want union formation. The prevalent factors that influence non-existence of union as identified in the study include high rate of unemployment and casual employment, the use of traditional apprenticeship, job insecurity and individualism caused by rigid, centralized and personalized management structure. A Union is a good collective bargaining strategy that regulates employment relations and supports the realization of corporate objectives (Iwuoha \& Chikwendu, 2014). Communication is the transfer of information from a source (sender) to a destination (receiver) with the information being understood by the receiver (Weihrich et al., 2010). An enterprise communication fosters attitude necessary for motivation, cooperation and job satisfaction (Briggs, 2002). An effective communication is indispensible to the promotion of industrial harmony and peace because it encourages subordinates to supply idea and suggestions, improves labour management relations and fosters social relations among workers. Survey findings revealed that small businesses in Port Harcourt city principally utilizes downward communication channel which is either under communicated or over communicated, lacks spontaneous feedback and causes resentment, distrust, gossip, feeling incompetence and insecurity (www.bizcommunicationcoach.com). It is derivable that downward communication negatively affects industrial peace and harmony and that explains why Lawal, Omotayo, Kolawole, Adedamola, and Igbalajibi (2010) recommend the use of all directional communication channels for effective employee participation, industrial harmony, remedial action and appropriate feedback.

A task is the duty to be done or undertaken that is clearly defined to make a task holder accountable. Furthermore, a clearly defined task enhances employee performance (Njoku \& Nwosu, 2010). Undesirably, the survey responses indicated negative relationship between task structure and employee performance. The adverse relationship between small enterprise task structure and employee performance in Port Harcourt as identified in the survey is caused by lack of specialization (due to mild division of labour and undefined task), rigid, centralized, non-institutionalized and generalized structure. A significant number of respondents indicated that their official duties occasionally take them to their superior's houses for domestic work. Decisively, small scale enterprise structure in Port Harcourt negatively affects an employee performance because performance is a function of an employee willingness, ability and compatibility with enterprise architecture that propels cordial and harmonious relations (Obijuru, 2007).

\section{Conclusion and Recommendations}

In conclusion, the study's findings revealed that small scale enterprise structure in Port Harcourt significantly and negatively affects industrial relations because of disorganized structure caused by rigid, one channel communication (downward) and generalized task configuration. Also, small business structure in Port Harcourt does not coordinate the mechanistic and humanistic aspects into cordial relationships with identification and delineation of authority, responsibility and accountability. As a result, small businesses in Port Harcourt city face industrial relations issues regarding ideal relationship, collectivism, industrial harmony, employee performance and enterprise productivity.

Based on the findings, it is recommended that small businesses in Port Harcourt should design and operate a formal structure with specialized task that is relatively flexible that will promote participatory and cordial relationship. This will invoke a better human development and relations, enhance interpersonal skills and collectivism and stimulate harmonious relations for mutual gains.

\section{Contribution/Originality of the Study}

This study contributes in existing literature in the design of formal, relatively flexible and specialized task structure that triggers ideal relationship in small enterprises. This study is one of the 
few studies which have investigated key dimensions of enterprise structure and industrial relations practice in small enterprises.

\section{References}

Ackers, P. (2002). Reframing employment relations: The case for neo-pluralism. Industrial Relations Journal, 33(1), 2-19. Available at: https://doi.org/10.1111/1468-2338.00216.

Agbonifoh, B. A., Ehiametalor, E. T., Inegbenebor, A. U., \& Iyayi, F. I. (1999). The business enterprise in Nigeria. Lagos: Longman Nigeria Plc.

Agu, C. N. (2001). Fundamentals of small business management and entrepreneurship development. Owerri: 1-o Publishers.

Akanwa, P. U. (2003). Principles of management. Owerri: Global Press Limited.

Ayozie, D., Jacob, S., Umukoro, F., \& Ayozie, V. (2013). Small and medium scale enterprises (SMEs) in Nigeria the marketing interface. Global Journal of Management and Business Research Marketing, 13(9), v1.

Briggs, B. R. (2002). Introduction to management. Port Harcourt: Ano Publications.

Briggs, B. R. (2009). Issues affecting Ugandan indigenous entrepreneurship in trade. African Journal of Business Management, 3(12), 786-797.

Briggs, B. R. (2014). Impact of globalization on industrial relations in the Nigerian banking sector. International Journal of Managment, IT and Engineering, 4(2), 179-196.

Bussing, A. (2002). Trust and its relations to commitment and involvement in work and organisations. Sa Journal of Industrial Psychology, 28(4), 36-42. Available at: https://doi.org/10.4102/sajip.v28i4.77.

Casio, W. F. (1986). Managing human resources: Productivity, quality of work life, profits. New York: McGraw-Hill.

Chikere, A. A. (2010). Business management: An introductory text (3rd ed.). Aba: Ezenwa- Ka Prnting Co.

Cole, G. A. (2004). Management theory and practice (6th ed.). Bedford Row, London: Book Power.

Ezirim, A. C., Briggs, B. R., Ebiringa, O. T., Akpobolokemi, P. Z., \& Maclayton, D. W. (2004). Research methodology for social sciences. Nnewi: MC Computer Press.

Gelfand, M. J., Bhawuk, D., Nishii, L. H., \& Bechtold, D. (2004). Individualism and collectivism. In R. J. House, P. J. Hanges, M. Javidan, P. W. Dorfman \& V. Gupta (Eds.), Culture, leadership \& organizations: The Globe study of 62 cultures (pp. 437-512). Thousand Oaks, CA: Sage Publications.

Igbara, N. (2012). Fundamentals of research. Port Harcourt: Dalitt Printing and Publishing.

Iwueke, O. C. (2016). Organizational behaviour (2nd ed.). Owerri: C-M Infinity Ventures.

Iwuoha, S. E., \& Chikwendu, C. O. (2014). Industrial relations in Nigeria: A fundamental approach (Revised ed.). Owerri: Ambix Printers.

Jones, G. R., George, J. M., \& Hill, C. W. L. (2000). Contemporary management (2nd ed.). USA: McGraw-Hill.

Kaufman, B. E. (2008). Paradigms in industrial relations: Original, modern and versions in-between. British Journal of Industrial Relations, 46(2), 314-339. Available at: https://doi.org/10.1111/j.1467-8543.2008.00676.x.

Kothari, C. R. (2004). Research methodology: Methods and techniques. New Delhi: New Age International Publishers.

Lawal, M. O., Omotayo, O. L., Kolawole, G. T., Adedamola, T. A., \& Igbalajibi, A. O. (2010). Journal of Communication and Culture: International Perspective, 1(3), 21-27.

Njoku, C. V., Nwosu, A. N., \& Callistus, M. O. (2017). Business management and entrepreneurship: A functional approach (Revised ed.). Owerri: Ambix Publishers.

Njoku, C. V., \& Nwosu, A. N. (2010). Principles of management: A fundamental approach. Owerri: Ambix Publishers.

Obi, J. N. (2015). The role of small scale enterprises in the achievement of economic growth in Nigeria. International Journal of Social Sciences and Humanities, 3(1), 1-27.

Obijuru, J. U. N. (2007). Principles of management (Revised ed.). Port Harcourt: Trumpet Press and Publishers.

Oparaku, U. D. (2013). Small business management. Owerri: Ambix Printers.

Oriyomi, S. M., Yinusa, M. A., Abdullateef, R., Omede, A. J., \& Abdulrasheed, S. L. (2016). Balanced employee and employer relationship: A mechanism for industrial development in Nigeria. Bangladesh e-Journal of Sociology, 13(2), 89-101.

Panigrahi, D. K. (2006). Industrial relations. New Delhi: UDH Publishers and Distributors.

Peretomode, V. F., \& Peretomode, O. (2001). Human resources management. Lagos: Obaroh and Ogbonaka Publishers.

Poole, M. (1986). Industrial relations: Origins and patterns of national diversity. Abingdon, Oxon: Routledge.

Rainnie, A. (1985). Is small beautiful? Industrial relations in small clothing firms. Sociology, 19(2), 213-224. Available at: https://doi.org/10.1177/0038038585019002005.

Ugiagbe, M. A., Nwaogwugwu, N. C., \& Obuseh, R. (2008). Entrepreneurship: Concept of small business management. Owerri: Favoured House Concept.

Weihrich, H., Cannice, M., \& Koontz, H. (2010). Management: A global and entrepreneurial perspective (13th ed.). New Delhi: Tata McGraw Hill Education Private Limited.

Zeb-Obipi, I. (2007). Frameworks of idustrial relations analysis: A re-visit of industrial relations theory. International Journal of Human Resources Management, 7(1), 1-12. 